\title{
UPAYA MENINGKATKAN HASIL BELAJAR EKONOMI DENGAN MENERAPKAN METODE TUTOR TEMAN SEBAYA PADA SMA NEGERI 1 PALANGKA RAYA
}

\author{
Oleh \\ Bayu Nurahma Suharo,* Ilham** \\ Email:ilham@gmail.com
}

\begin{abstract}
This study aims to determine: learning outcomes and economic learning activities using the Peer Friend Tutor Method in Class Students. The method used in this study is to use a Classroom Action Research (CAR) design that seeks to overcome the problems faced in the current situation. The subjects needed in this study were students of class XI IPS 1 in SMA 1 Palangka Raya, which numbered 40 students. The results of the study show that: (1) the learning activities of the class students are very good. The results of observations of the first cycle of learning activities of students gained a score of 3.03 with good criteria, and the second cycle of activities of students experienced an increase in obtaining a score of 3.81 with good criteria. (2) There is an increase in economic learning outcomes. In the classical pre-test there were $17.5 \%$ of students who completed with an average score of 59.75. After being implemented in the first cycle of students who completed it increased to $67.5 \%$ of students who completed classically with an average of 78.12. In the second cycle classically $97.5 \%$ of students completed with an average value of 86.25
\end{abstract}

(C) Muhammadiyah University Palangkaraya

Keywords: Economic Learning Outcomes, Peer Friend Tutors

ABSTRAK
Penelitian ini bertujuan untuk mengetahui: hasil belajar dan aktivitas pembelajaran ekonomi menggunakan Metode Tutor Teman Sebaya Pada Peserta Didik Kelas. Metode yang digunakan dalam penelitian ini adalah menggunakan rancangan Penelitian Tindakan Kelas (PTK) yang berusaha mengatasi permasalahan yang dihadapi pada situasi sekarang. Subjek yang dibutuhkan dalam penelitian ini, adalah peserta didik kelas XI IPS 1 SMA Negeri 1 Palangka Raya yang berjumlah 40 orang peserta didik. Hasil penelitian menunjukan bahwa: (1) Aktivitas pembelajaran peserta didik kelas menjadi sangat baik. Hasil pengamatan siklus I aktivitas belajar peserta didik memperoleh skor 3,03 dengan kriteria baik, dan siklus II aktivitas peserta didik mengalami peningkatan memperoleh skor 3,81 dengan kriteria baik. (2) Ada peningkatan hasil belajar ekonomi. Pada pre-test secara klasikal terdapat 17,5\% peserta didik yang tuntas dengan rata-rata nilai 59,75. Setelah dilaksanakan pada siklus I peserta didik yang tuntas meningkat menjadi $67,5 \%$ peserta didik yang tuntas secara klasikal dengan rata-rata 78,12. Pada siklus II secara klasikal 97,5\% peserta didik yang tuntas dengan nilai rata-rata 86,25 .

(C) Universitas Muhammadiyah Palangkaraya

Kata Kunci : Hasil Belajar Ekonomi, Tutor Teman Sebaya

Bayu Nurahma Suharo* Mahasiswa FKIP UM Palangkaaraya

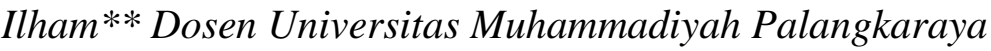




\section{PENDAHULUAN}

Pendidikan merupakan kebutuhan mendasar bagi manusia dalam rangka untuk meningkatkan sumber daya manusia. Hal ini sesuai dengan tujuan pendidikan nasional sebagaimana yang tertuang dalam Undang- Undang RI Nomor 20 Tahun 2003 tentang Sistem Pendidikan Nasional adalah sebagai berikut : Pendidikan nasional berfungsi mengembangkan kemampuan dan membentuk watak serta peradaban bangsa yang bermartabat dalam rangka mencerdaskan kehidupan bangsa, bertujuan untuk berkembangnya potensi peserta didik agar menjadi manusia beriman dan bertakwa kepada Tuhan Yang Maha Esa, berakhlak mulia, sehat, berilmu, cakap, kreatif, mandiri dan menjadi warga negara yang demokratif serta bertanggung jawab.

Dalam rangka mencapai tujuan pendidikan nasional, ada banyak hal yang harus dipersiapkan dan diperhatikan terutama yang berkaitan dengan masalah pendidikan, diantaranya adalah faktor guru, peserta didik, kurikulum, metode, sarana dan prasarana dan lain sebagainya. Dalam proses pembelajaran di kelas sering kali menghadapi banyak permasalahan. Salah satunya adalah kurangnya hasil belajar peserta didik di dalam proses pembelajaran. Hasil belajar peserta didik merupakan sebuah bentuk kerja keras antara peserta didik dengan tenaga pendidik dalam pembelajaran dikelas. Hasil dalam sebuah proses pembelajaran mempunyai peranan penting dalam rangka untuk memahami suatu materi mata pelajaran tertentu.
Pembelajaran yang digunakan seseorang dalam menyampaikan materi mata pelajaran kepada peserta didik sangat menentukan dalam tercapainya tujuan pembelajaran. Sering kita jumpai masih banyaknya proses belajar mengajar dikelas kurang mendorong peserta didik untuk bersemangat mengikuti pembelajaran. Pada prinsipnya materi akan mudah dipahami, dimengerti dan diterima oleh peserta didik jika proses pembelajarannya itu lebih terasa menyenangkan dan membuat peserta didik tertarik untuk memperhatikan dan memahami materi yang telah disampaikan.

Menurut Pinarac (2012) tujuan metode pembelajaran adalah: Metode bertujuan mengantarkan sebuah pembelajaran searah tujuan tertentu yang ideal dengan tepatdan cepat sesuai yang diinginkan. Karenanya terdapat suatu prinsip yang umum dalam memfungsikan metode yaitu prinsip agar pembelajaran dapat dilaksanakan dalam suasana menyenangkan, menggembirakan penuh dorongan dan motivasi sehingga materi pembelajaran itu menjadi lebih mudah untuk diterima peserta didik.

Guru memiliki peran yang sangat penting guna menciptakan kondisi belajar yang efektif dan efisien sehingga memungkinkan proses pembelajaran dapat mencapai tujuan yang baik. Salah satu kompetensi yang harus dilakukan dan dimiliki oleh seorang guru adalah guru harus dapat memilih, mengembangkan dan menggunakan metode pembelajaran yang ada. Hal ini sangatlah penting karena dapat 
membantu guru dan tenaga pengajar dalam menyampaikan materi pembelajaran lebih cepat dan lebih mudah dipahami dan ditangkap oleh peserta didik. Metode pembelajaran memiliki kekuatan-kekuatan yang positif dan sinergi yang mampu merubah sikap dan tingkah laku, hasilnya mereka kearah perubahan yang dinamis dan kreatif. Sehubungan dengan hak itu, peran metode seperti Tutor Teman Sebaya sangat dibutuhkan dalam pembelajaran dimana sekarang metode tidak hanya sebagai alat bantu saja melainkan bagian yang integral dalam sistem pendidikan dan pembelajaran.

Penggunaan Tutor Teman Sebaya sebagai metode pembelajaran merupakan konsep pembelajaran yang menekankan pada keterkaitan antara materi pembelajaran dengan peserta didik. Tujuannya agar peserta didik dapat memahami apa yang sudah guru atau pendidik sampaikan yang telah dirumuskan dan sesuai, maka seorang pendidik atau pengajar perlu mengetahui dan mempelajari beberapa metode mengajar, serta mempraktekan secara langsung dalam mengajar.

Ada beberapa teori yang mendasari strategi pembelajaran tutor teman sebaya yaitu: Menurut Akhmad Sudrajat (2011:140) mengatakan bahwa: Tutor teman sebaya adalah kegiatan pembelajaran yang dilakukan seorang siswa kepada siswa lainnya yang salah satu siswa itu lebih memahami materi pembelajaran. Bantuan belajar yang diberikan oleh teman sebaya dapat menghilangkan rasa kecanggungan seperti halnya dengan guru. Bahasa yang digunakan antara teman dengan teman lebih dapat dipahami dari pada guru dengan siswa. Sedangkan Conni Setiawan (Mahmud 2011:97) mengemukakan bahwa tutor teman sebaya adalah peserta didik yang pandai memberikan bantuan belajar kepada peserta didik yang kurang pandai. Bantuan tersebut dapat dilakukan teman-teman diluar sekolah. Mengingat bahwa peserta didik elemen pokok dalam pengajaran. Kemudian Abu Ahmadi dan Widodo Supriyono (2011:184) berpendapat bahwa tutor yaitu siswa yang sebaya ditunjuk atau ditugaskan membantu temannya yang mengalami kesulitan belajar, karena hubungan antara teman umumnya lebih dekat dibandingkan hubungan gurusiswa Dapat disimpulkan bahwa metode tutor sebaya suatu metode pembelajaran yang memanfaatkan potensi diri pada peserta didik yang berprestasi untuk menularkan potensinya kepada peserta didik yang memiliki prestasi rendah agar dapat mengejar ketertinggalannya. Pada perkembangan dunia pendidikan seperti saat ini metode tutor teman sebaya mulai diterapkan dibeberapa sekolah dengan tujuan untuk menarik perhatian peserta didik sehingga meninkatkan hasil belajar peserta didik.

Bantuan yang diberikan oleh teman untuk teman pada umumnya dapat memberikan hasil yang lebih baik. Kegiatan tutor teman sebaya ini bagi peserta didik merupakan kegiatan yang sangat kaya akan pengalaman yang sebernarnya merupakan kebutuhan peserta didik itu sendiri, tutor maupun yang ditutori akan sama-sama 
mendapatkan keuntungan, bagi tutor akan mendapatkan pengalaman yang sudah ia terima, sedangkan yang ditutori akan lebih kreatif dalam menerima materi pelajaran. Dengan demikian akan terciptanya suasana pembelajaran yang menyenangkan dan efektif bagi peserta didik, sehingga peserta didik dapat mengoptimalkan potensi yang dimiliki dan tentunya hasil belajar ekonomi akan lebih meningkat.

Berdasarkan pengamatan yang dilakukan oleh peniliti saat melakukan observasi di kelas XI - IPS 1 SMA Negeri 1 Palangka Raya pada pembelajaran Ekonomi, terdapat beberapa permasalahan yang terjadi saat kegiatan pembelajaran berlangsung, masalah tersebut diantaranya kurang meratanya pemahaman peserta didik dalam proses pembelajaran, dimana peserta didik ada yang cepat memahami dan masih banyak peserta didik yang kurang memahami materi yang sudah disampaikan. Hal ini terlihat dari ketika seorang guru menyampaikan materi, peserta didik jarang bertanya kepada seorang guru bila ada yang tidak mengerti atau kurang jelas, kecuali peserta didik tertentu saja. Peserta didik sering bertanya kepada temannya dari pada bertanya kepada seorang guru, karena peserta didik malu dan takut untuk bertanya dan memilih bertanya kepada teman sebayanya apabila ada materi yang kurang jelas dipahami. Banyaknya peserta didik yang kurang bersemangat, kurang berpartisipasi dan cenderung bosan dalam proses pembelajaran ekonomi, karena metode yang digunakan kurang bervariatif hanya ceramah, tanya jawab dan penugasan saja.

Berdasarkan data yang peneliti dapatkan, hasil belajar khususnya mata pelajaran Ekonomi peserta didik kelas XI - IPS 1 SMA Negeri 1 Palangka Raya perlu ditingkatkan lagi karena masih terdapat beberapa peserta didik yang mendapatkan nilai dibawah Kriteria Ketuntasan Minimal (KKM). KKM mata pelajaran Ekonomi yaitu 80, dari 41 peserta didik, ada 26 peserta didik $(63,4 \%)$ yang masih mendapatkan nilai dibawah 80 , yang mendapatkan nilai sesuai dengan KKM ada 5 peserta didik (12,2\%), dan yang mendapatkan nilai di atas 80 ada 10 peserta didik $(24,4 \%)$, dengan nilai tertinggi 95 dan nilai terendah 45 . Hasil belajar tersebut perlu ditingkatkan lebih tinggi lagi dari nilai KKM yang telah ditentukan. Memperhatikan permasalahan-permasalahan yang terjadi khususnya pada peserta didik kelas XI - IPS 1 SMA Negeri 1 Palangka Raya, maka peneliti merasa penggunaan metode tutor teman sebaya akan lebih tepat karena keadaan dan karakteristik peserta didik yang berbeda- beda, karena peserta didik lebih nyaman bertanya dengan temannya dibandingkan kepada guru.

Hal ini yang menyebabkan peneliti tertarik untuk mengadakan penelitian lebih lanjut tentang Upaya Meningkatkan Hasil Belajar Ekonomi Dengan Menerapkan Metode Tutor Teman Sebaya Pada SMA Negeri 1Palangka Raya.

\section{METODE PENELITIAN}

Jenis penelitian yang digunakan dalam penelitian ini adalah penelitian 
tindakan kelas (PTK). Dalam penelitian ini berusaha untuk memecahkan atau menjawab permasalahan yang di hadapi pada situasi tertentu.

Menerut Kunandar (2010:46), Penelitian tindakan kelas adalah suatu penelitian yang berbasis kepada kelas. Penelitian dapat dilakukan secara mandiri, tetapi alangkah baiknya dilaksanakan secara kolaboratif, baik dengan teman sejawat, kepala sekolah, pengawas, dosen dan pihak yang relevan dengan PTK.

Menurut Paizaludin dan Ermalinda (2016:7): Penelitian tindakan kelas adalah suatu kegiatan penelitian dengan mencermati sebuah kegiatan belajar yang di berikan tindakan, yang secara sengaja dimunculkan dalam sebuah kelas, yang bertujuan memecahkan masalah atau meningkatkan mutu pelajaran di kelas tersebut.

Berdasarkan beberapa pendapat di atas dapat disimpulkan bahwa penelitian tindakan kelas adalah penelitian yang dilakukan guru secara sistematis dalam melaksanakan kegiatan belajar yang berupa tindakan dalam kelas secara bersama melalui refleksi diri untuk meningkatkan hasil belajar peserta didik. PTK dilaksanakan dengan strategi siklus yang berangkat dari identifikasi masalah yang dihadapi pendidik. Penyusunan rencana tindakan, pelaksanaan tindakan, observasi tindakan dan refleksi. Rangkaian kegiatan berurutan mulai dari rencana tindakan sampai dengan refleksi disebut satu siklus penelitian.

\section{HASIL DAN PEMBAHASAN}

Hasil penelitian yang diperoleh dariaktivitas pembelajaran ekonomi Pada Peserta Didik di Kelas XI- IPS 1 SMA Negeri 1 Palangka Raya menggunakan Metode Tutor Teman Sebaya ini memuat pengolahan hasil data yang dapat diuraikan sebagai berikut:

Hasil Observasi Aktivitas Guru dan Peserta Didik. Pada tahap awal disaat observasi sebelum menerapkan siklus I dan II dengan menerapkan metode tutor teman sebaya tingkat hasil belajar peserta didik masih rendah, namun ketika diterapkan pada siklus I aktivitas belajar peserta didik dari 40 peserta didik rata-rata hasil pengamatan aktivitas yaitu 3,03 dengan kriteria baik, dan pada siklus II meningkat menjadi 3,81 dengan kriteria sangat baik.

Nilai Hasil Belajar Peserta Didid. Hasil belajar peserta didik yang diperoleh berdasarkan pada hasil tes dari pra tindakan peserta didik memperoleh rata-rata 59,75 dengan ketuntasan klasikal 17,5\%, sedangkan pada post-test saat pada siklus I hasil belajar peserta didik memperoleh nilai rata-rata 78,12 dengan ketuntasan klasikal $67,5 \%$ dan pada siklus II ada peningkatan hasil belajar peserta didik memperoleh nilai rata-rata 86,25 dengan ketuntasan klasikal 97,5\% dengan demikian pada saat siklus II memenuhi ketercapaian ketuntasan terhadap hasil belajar peserta didik secara klasikal sehingga peneliti menganggap pada siklus II ini berhasil. 


\section{KESIMPULAN}

Aktivitas belajar peserta didik kelas XI IPS 1 SMA Negeri 1 Palangka Raya dengan menerapkan metode tutor teman sebaya menjadi baik, dalam mengikuti pembelajaran dan memperhatikan penjelasan yang dijelaskan oleh guru, ini dapat dilihat pada siklus I aktivitas belajar peserta didik memperoleh skor 3,03 dengan kriteria baik, sedangkan pada siklus II aktivitas peserta didik mengalami peningkatan memperoleh skor 3,81 dengan kriteria baik.

Ada peningkatan hasil belajar setelah menerapkan metode tutor temansebaya pada peserta didik kelas XI IPS 1 SMA Negeri 1 Palangka Raya. Pada pre-test secara klasikal terdapat $17,5 \%$ peserta didik yang tuntas dengan rata-rata nilai 59,75. Setelah dilaksanakan pada siklus I peserta didik yang tuntas meningkat menjadi $67,5 \%$ peserta didik yang tuntas secara klasikal dengan rata-rata 78,12. Pada siklus II secara klasikal $97,5 \%$ peserta didik yang tuntas dengan nilai rata-rata 86,25.

\section{DAFTAR PUSTAKA}

Abu Ahmadi \& Widodo Supriyono. (2008). Psikologi Belajar. Jakarta: CV. Rineka Cipta

Akhmad Sudrajat. (2011). Kurikulum dan Pembelajaran Paradikma Baru.

Kunandar, 2010. Langkah Mudah Penelitian Tindakan Kelas Sebagai Pengembangan Profesi Guru Edisi Revisi. Jakarta: PT Raja Grafindo Persada

Mahmud. (2011). Metode Penelitian Pendidikan. Bandung: PT. Pustaka Setia

Paizaludin dan Ermalinda. (2016). Penelitian Tindakan Kelas. Bandung: Alfabeta

Pinarac. (2012). Tujuan Metode Pembelajaran. (online): https://pinarac.wordpress.com/20 12/04/05/tujuan-metodepembelajaran/ (diakses 31 Januari 2018).

Undang-Undang RI No.20 Tahun 2003 Tentang Sisdiknas. Yogyakarta: Media

Abadi 